\title{
Kunskapens värde och samhällets behov
}

\author{
MARGARETA BÄCK-WIKLUND
}

Socialt arbete som begrep användes ursprungligen vid förra seklet 1900 i samband med att Centralförbundet för Socialt Arbete (CSA) bildades. Utbildningen av socialarbetare kom snabbt igång genom CSA:s initiativ, och grunden lades för en nyyrkesgrupp. Men det tog 70 år att fä forskning i direkt anslutning till utbildningen. Under århundradet har olika dimensioner adderats till innebörden av socialt arbete. De är uttryck för såväl specifika kunskapsintressen som samhälleliga behov.

Vid sekelskiftet 1900 lades grunden till många av Sveriges välfärdsinstitutioner. 100 år senare finns tecken på att den välfärd som byggts upp under det gångna seklet utmanas och ifrågasätts. Välfärdsbokslutet 2000 ger i blixtbelysning en bild av läget i landet eller uttryckt med förra sekelskiftets ord "den sociala frågan«. Bokslutets resultat visar att trots det senaste decenniets stora påfrestningar, så är de svenska välfärdssystemen generellt sett förhållandevis motståndskraftiga. Men det finns

\footnotetext{
Margareta Bäck-Wiklund är professor i socialt arbete med inriktning på familjepolitik vid Göteborgs universitet och ordförande för Centralförbundet för Socialt Arbete. Hon forskar om barn och familj och har givit ut ett flertal böcker inom området.
}

också undantag och ungdomar, invandrare och ensamma mammor är det sena 1900 talets stora förlorare och utgör majoriteten av socialtjänstens klienter (SOU 2000:3). Dessa grupper har i allt större utsträckning fått lita till de selektiva välfärdsinstitutionerna och varje individ har som enskilt fall handlagts och prövats av socialtjänsten för stöd, hjälp och försörjning.

I Sverige finns ett utbrett förtroende för välfärdsstatens gemensamma institutioner, ett förhållande som varit oförändrat under lång tid. I ett samhälle med så omfattande kollektiva åtaganden för individens välfärd som det svenska måste människors relationer bygga på tillit till varandra, för att tilltron till det gemensamma skall fungera - och omvänt. Gemensamma institutioner 
fungerar också som en bas för att bygga mänsklig tillit. Idéhistorikern Roger Qvarsell (1995) hävdar i en essä om det sociala ansvarets organisering under två århundraden, att Sverige i det avseendet skiljer sig från andra europeiska länder. Statens roll både politiskt och ideologiskt har varit och är betydelsefull. Detta bygger på en unik svensk tradition med den enskilde medborgarens rätt att "gå till kungs» om man blivit felaktigt behandlad av myndigheterna. Staten har inte uppfattats som företrädare för elitens intressen utan bildat grunden för "föreställningen om en god och rättrådig statsmakt» (Qvarsell 1995, s. 20).

Under de senaste åren finns tecken på att de som har direkta erfarenheter av institutioner vilka fördelar behovsprövad service och tjänster (t.ex. bostadsbidrag och socialtjänst) tenderar att minska i sin tillit. Högsta andelen med låg tillit finns hos dem som har haft kontakt med två eller flera selektiva institutioner (Rothstein \& Kumlin 2001). Det finns alltså en risk att välfärdssystemen är på väg att förlora sin legitimitet bland dem som är materiellt beroende av dem för sitt uppehälle. Men legitimiteten hotas också från den del av den välbeställda medelklassen som aktivt ifrågasätter kvaliteten på skolor, barnomsorg och sjukvård och som i valfrihetens namn kräver privata alternativa välfärdstjänster (se t.ex. Granqvist 1997, Möller 2002). I en situation med ifrågasatt legitimitet är det självklart att det politiska intresset för välfärdsstatens institutioner ökar och krav på effektivitet, resultatuppföljning och system för kvalitetssäkring artikuleras.

Kontakten med socialtjänsten kan för den enskilde innebära såväl hjälp som stöd men det kan också innebära djupa ingrepp i den personliga sfären. Det är därför viktigt att människor behandlas med respekt, att handlingarna är etiskt försvarbara och bygger på "vetenskap och beprövad praxis». Under senare år har emellertid socialtjänsten utsatts för kritik för att arbetet utförs utifrån en bristfällig kunskapsbas och att man till stor del saknar systematiska uppgifter och kunskap om sina egna resultat. Från Socialstyrelsen har kravet ställts på "ett kunskapsbaserat arbete", en term som efterhand blivit den vedertagna istället för den strängare »evidens». Att skapa säkra kunskaper baserade på människors handlingar och utsagor är något av socialvetenskapens akilleshäl och därför intar forskaren ofta en ödmjuk inställning till sina forskningsresultat. Det är helt enkelt nödvändigt att ha rimliga förväntningar på vad man kan åstadkomma med forskning. För socialt arbete gäller också att det funnits som praktisk verksamhet och paraplybegrepp för sin tids sociala problem, långt innan det blev ett akademiskt forskningsämne.

Vad betyder då de historiska rötterna för synen på kunskap i relation till socialt arbete? Det är en fråga som kan besvaras på många sätt och mitt syfte är inte att täcka den i hela dess vidd. Min ambition är betydligt mer begränsad och syftar till att frilägga några av de dimensioner, som i olika situationer framstår som motsättningar i synen på socialt arbete. I dagligt tal förknippar vi socialt arbete med företeelser såväl på samhällsnivå som på individnivå. Nivåerna återspeglar också uppfattningen om vad som av tradition setts som det sociala arbetets två hörnstenar - socialpolitiken 
och mötet med klienten (Lindholm 1988). Relationen samhälle - individ är också en av socialvetenskapens klassiska distinktioner. Distinktionen och dess konsekvenser för kunskapssyn, forskning och yrkesroll är den röda tråden i föreliggande uppsats. Utgångspunkten för analysen är förra århundradets sekelskifte och kopplingen mellan begreppet socialt arbete, etablerandet av en utbildning av socialarbetare, den sociala frågan samt kartläggningen av samtidens sociala problem. I analysen ingår också hur frågan om forskning $i$ anslutning till socialarbetarutbildningen hanterats från sekelskiftet 1900 och fram till slutet på 1970-talet, när den första professuren $\mathrm{i}$ socialt arbete inrättades i direkt anslutning till utbildningen.

\section{Socialtjänsten och forskningen}

Socialt arbete som ett akademiskt forskningsämne inrättades 1977 och har uppfattats ha ett särskilt mandat att utveckla kunskapsbasen för socialtjänstens verksamheter, något som inte har kommit att motsvara förväntningarna. Företrädare för forskningsanvändarna ställer forskningens frihet mot samhällets behov av användbar kunskap. Kritiken avser både forskningens inriktning, vilka frågor och problemområden den tar sig an, och om forskningens resultat är möjliga att omsätta i det praktiska sociala arbetet. Dessa frågor har ventilerats såväl i den offentliga debatten som i fackpress och rapporter (se t.ex. Tengvald 1995, 2001, Månsson 2000, 2002). Från Socialstyrelsen som tillika är socialtjänstens och det praktiska sociala arbetets yttersta tillsynsmyndighet, ges följande påpekanden offentlighet:

„Forskningen är här (avser universitetsinstitutionerna för socialt arbete) $i$ stor utsträckning inriktad på studier av sociala fenomen och sociala problem $i$ allmänhet och $i$ alltför liten utsträckning inriktad pa att undersöka resultaten av det sociala arbetet»(Wigzell 1999).

Men kritiken har också formulerats mer direkt och detaljerat.

"forskarna har $i$ huvudsak anlagt olika slags kvalitativa analyser för att beskriva kvalitativa aspekter av det sociala arbetet, eller sökt att beskriva 'processer' $i$ samspelet mellan de professionella aktörerna och klienterna. Det sociala arbetets 'väsen 'har intresserat mer än dess konsekvenser för klientens del«(Socialstyrelsen 2002, s. 37).

Det finns mycket som talar för att den existerande forskningen har en betydligt större bredd och metodblandning än vad som avses ovan (se t.ex. Dellgran \& Höjer 2000, 2002). Ett nytt forskningsämne med stor samhällsrelevans måste för sin överlevnad finna legitimitet i såväl den akademiska världen som bland avnämare. Det är en erfarenhet som flera akademiska ämnen (jfr företagsekonomi och pedagogik) med ett praktikerfält tvingats handskas med (Dahlström 1980, Bäck-Wiklund 1993). Uttalandena ovan är emellertid upptakten till utredningen "Nationellt stöd för kunskapsutveckling inom socialtjänsten" (Socialstyrelsen 2001). Utredningen har letts av en styrgrupp med Socialstyrelsens 
generaldirektör och två överdirektörer som medlemmar. Till denna grupp har kopplats en referensgrupp med representanter för olika intressenter; Kommunförbundet, fackliga organisationer, socialhögskolorna, Högskoleverket, lokala FOU - enheter samt Föreningen Sveriges Socialchefer. I utredningen diskuteras det praktiska sociala arbetets komplexa natur, vidare presenteras en rad konkreta förslag om hur kunskapsbildningen på vilken socialtjänstens verksamhet bygger skall organiseras för att det praktiska arbetet skall förbättras och utgöras av :

"strategier för hur kunskap om nytta och resultat för den enskilde kan utvecklas och användas inom socialtjänsten. En sådan utveckling inkluderar bl. a. interventioner där effekter av metoder och arbetssätt studeras" (Socialstyrelsen 2002, s. 8).

För att åstadkomma de önskade förändringarna föreslås en rad olika åtgärder som direkt och indirekt syftar till att påverka både den sociala forskningen och utbildningen av socialarbetare. Det innebär en klart deklarerad avsikt att påverka kunskapsutvecklingen "genom den statliga utbildningen och forskningen, riktlinjer och normering" (Socialstyrelsen 2002, s. 9). Det handlar bl. a. om att påverka forskningsfinansiärer, stödja inrättandet av forskarskolor och skapa fora för samverkan mellan forskning, utbildning och praktik.

Den "kunskap" som avses är också klart angiven och utgörs av: wverktyg att systematiskt och metodiskt pröva erfarenheter, medan problemställningarna hämtas ur den professionella verksamheten" (Soci- alstyrelsen 2002, s. 45). Det avser randomiserade experiment där man kan mäta effekten av den gjorda insatsen samt systematiska kunskapsöversikter och s.k. metaanalyser. Denna typ av kunskap har numera ett internationellt nätverk vars syfte är att mutveckla, upprätthålla och sprida systematiska litteraturöversikter av insatsers och sociala programs effekter inom socialt arbete, kriminalvård och utbildning" (Campbell Collaboration, Programförklaring). Socialarbetaren skall i sin praktiska verksamhet kunna välja den insats som med statistisk säkerhet ger det bästa utfallet för klienten.

Genom försöken att styra forskning och undervisning utmanar staten genom Socialstyrelsens dekret socionomerna som yrkesgrupp. På samma sätt utmanas också forskarna i socialt arbete - en grupp som både gör sig hörda och i kraft av sin kompetens utmanar föreställningen om forskningens styrning av externa krafter. Att forskning sker på välfärdsstatens mandat är emellertid inget nytt och den socialvetenskapliga forskningen i Sverige är starkt kopplad till välfärdsstatens framväxt. Samma förhållanden som riktar sökljuset på socialtjänsten gäller även för forskningen och utvärderingar görs på löpande band samtidigt som de statliga anslagen till forskning urholkas. Med krympande anslag till universitetens forskning och ökade krav på att finna externa finansiärer så blir det helt enkelt arbetsamt och ibland konfliktfyllt att tillfredsställa många uppdragsgivare. Forskarna protesterar när deras makt minskar och externa krafter tenderar att sätta dagordningen.

Såväl forskare som socialarbetare tillhör 
välfärdsstatens egna yrkesgrupper. Förhållandet mellan välfärdsstaten och dess olika yrkesgrupper antas innehålla gemensamma villkor och målsättningar. I många avseenden drar stat och yrkesgrupp åt samma håll. Men det är också uppenbart att när yrkesgrupper når en viss självständighet och gör anspråk på professionell status med kunskaps- och yrkesmonopol, så uppstår lätt en kamp om tolkningsföreträdet om vad som är "gott och rättrådigt« och kostnadseffektivt.

Modellen om den evidensbaserade kunskapen är hämtad från det medicinska verksamhetsfältet som antas vara en bra förebild för det sociala arbetet vad avser vetenskaplig bas och beprövad erfarenhet. För att ge detta ett perspektiv finns anledning att kommentera både omfattningen och kopplingen mellan praktik och forskning inom det sociala arbetet liksom det sociala arbetets kunskapsbas i förhållande till medicinen. En jämförelse av antalet med forskarbakgrund i förhållande till antalet yrkesverksamma inom de båda verksamhetsområdena visar att det är stora skillnader i förutsättningarna för att erhålla en på vetenskap grundad praktik (Dellgran \& Höjer 2000). Inom medicin fanns 199735000 yrkesverksamma (tandläkare inkluderade) och totalt 624 professurer. Inom socialt arbete fanns 28000 totalyrkesverksamma och totalt 10 professurer. För 1000 yrkesverksamma inom medicin fanns 17,8 professorer, 19,6 med doktorsexamina och 127 aktiva doktorander. Motsvarande antal för socialt arbete är 0,4 professorer, 0,4 med forskarutbildning och 5,3 doktorander. Vidare sker delar av den medicinska forskningen i direkt anslutning till dess tillämpning vilket inte är fallet inom socialt arbete. I det senare fallet har det skett en viss förändring i och med inrättandet av en rad FOU - enheter i vilka forskning och utredning förväntas ske i ett nära samspel med verksamheternas frågeställningar och med praktiker involverade.

Jämförelsen mellan de två verksamhetsområdena och dess "vetenskaplighet" visar på stora skillnader i förutsättningar. Minst var sjunde person av de yrkesverksamma inom medicinen arbetar samtidigt med vetenskaplig verksamhet. Det ger status, är en självklar del av praktiken liksom det är inbyggt i flera yrkesgruppers karriärvägar. Det kan man knappast säga gäller för socialt arbete. En uppföljning av dem som disputerat i ämnet fram till 1990-talets mitt visar att endast några få av den tredjedel, som när de påbörjade sina doktorandstudier fanns inom det sociala praktikerfältet, återvände dit efter disputationen (Kihlström \& Karlsson 1996).

En jämförelse mellan näraliggande vetenskapsområden som psykologi och sociologi med en begränsning till det vetenskapliga samhället där medelstilldelningen skett i konkurrens ger en annan bild. Socialt arbete har som nytt forskningsämne $i$ konkurrensen om anslag visat sig vara en jämnbördig bland likar. Socialforskningsrådets (SFR) årsredovisning från 2000 visar följande. Socialt arbete erhöll vid slutet av 1990-talet ca 12 procent av de fördelade medlen, sociologi 18 procent och psykologi 10 procent. Under en sexårsperiod (1993-1999) ökade anslagen från SFR till ämnet socialt arbete med drygt 50 procent. Under samma period skedde en omfattande 
ökning av anslagen till vissa tillämpningsområden av relevans för socialt arbete. Som exempel kan nämnas att barn och familj och missbruk under samma period fick sina anslag mer än fördubblade. Forskning med "socialtjänst" som objekt expanderade i mitten på 1990-talet för att vid periodens utgång vara tillbaka till utgångsläget. (Socialvetenskapliga forskningsrådets årsredovisning 1999). ${ }^{1}$

Ett tema i kritiken av den universitetsbaserade forskningen är att resultaten tar lång tid att få fram och att den har en bristande förankring i praktikervärlden. Motsatsen gäller för den FOU - baserade forskningen. Den kritiseras istället för sin ad hoc karaktär och bristande förankring inom universitetsvärlden (Socialstyrelsen 2002). När det gäller kunskapsbasen för socionomer och läkare kan man heller inte bortse från att läkarna som yrkesgrupp är en av de klassiska professionerna som sedan länge åtnjutit statlig legitimation. Deras kunskap värderas som nyttig och värdefull, och läkarna har genom ett organiserat strävande tillåtits att etablera ett kunskapsoch yrkesmonopol (Hellberg 1978). Villkoren för socialarbetarna som yrkesgrupp ser mycket annorlunda ut. Sedan 1977 finns socialt arbete som ett forskningsämne inom universitet och högskolor. Men socialarbetarna har trots trägna försök sedan slutet av 1950-talet, och med stor intensitet under senare år, inte lyckats erhålla ett kunskaps-

1 År 2000 slogs Socialvetenskapliga Forskningsrådet och delar av Rådet för Arbetslivsforskning samman. Därigenom uppstod nya grupperingar avseende forskningsobjekt och området «socialtjänst « försvann som enskilt område och senare års förändringar kan inte avläsas. och yrkesmonopol genom en statlig legitimering (Wingfors 2001).

\section{Socialt arbete och den nsociala fråganı}

"Den sociala frågan" och bildandet av Centralförbundet för Socialt Arbete - CSA är intimt sammankopplade. 1903 slöt sig en $\mathrm{rad}$ frivilligorganisationer samman till ett gemensamt förbund. När samhället omvandlades från bondesamhälle till industrisamhälle framträdde en rad nya problem bl. a. som en följd av att familjens, arbetsgivarens och kyrkans självklara norm- och värdesystem började ifrågasättas. I samhällets ledarskikt fanns en rädsla för att misär och nöd skulle leda till social oro. I många länder uppmärksammades problemen och förslag på lösningar lanserades. 1906 ordnade CSA en kongress på temat "Fattigvård och folkförsäkring" under vilken hemortsrätten, barn och ungdom, försumliga fäder, äldre och handikappade avhandlades ur ett försörjningsperspektiv. De frågor som diskuterades, de fakta som presenterades, ofta i direkt jämförelse med andra europeiska länder, ger sammantaget en uppfattning om den sociala frågan i svensk tappning vid förra sekelskiftet, liksom välfärdsbokslutet ger en lägesbild av de sociala förhållandena vid 2000-talets början.

CSA var initialt en socialpolitisk kraftfull maktfaktor vars agerande bidragit till att många nu viktiga samhällsinstitutioner som Svenska Kommunförbundet, Socialstyrelsen 1912 och Socialdepartementet 1920 inrättats. Enligt förbundets första stadgar var syftet: »att inom olika samhällslager 
söka väcka intresse för att sprida kunskap om sociala spörsmål för att därigenom medverka till lösningen av viktiga samhällsspörsmål«. 1922 antog förbundet nya stadgar och därmed skedde en förskjutning av verksamheten mot upplysning (Berglind 1997). Juvelen i kronan var Social Årsbok, som kom ut under åren 1939 - 1954. Bland dess redaktörer fanns en rad i socialpolitiska sammanhang namnkunniga personer, däribland Alva Myrdal, Ulla Lindström och Karl-Johan Höjer. Förbundets begränsade resurser gjorde att Social Årsbok fick läggas ned.

CSA:s glansperiod var 1900-talets två första decennier och antalet medlemsorganisationer var mellan 60-70. Dess agerande bidrog till en omfattande utredningsverksamhet och lagstiftning inom det socialpolitiska området (för en närmare diskussion om detta, se Edebalks artikel „Folkpension och åldringsvård - om svensk socialpolitik 1903-1950« i detta nummer). De organ, vars tillkomst CSA bidragit till, tog över delar av det fortsatta socialpolitiska arbetet. De första 20 åren var omvälvande, därefter har verksamheten varit av betydligt mindre omfattning. CSA försvagades bl.a. genom alla socialpolitiska initiativ som den socialdemokratiska regeringen med stöd av LO aktivt engagerade sig i (Lindholm 1993).

1952 antogs nya stadgar där det också sägs att det huvudsakliga ändamålet är att "främja forskning på socialpolitikens område och därigenom bidra till klarläggandet av förutsättningarna för framgångsrikt socialt arbete». Denna formulering finns även i nu gällande stadgar (fastställda av Kunglig Maj:t 1974). Verksamheten består vid 2000-talets början av att i begränsad utsträckning ekonomiskt stödja enskilda forskare för att via skrifter, symposier och konferenser skapa mötesplatser för forskare och socialt verksamma praktiker. CSA:s medlemsorganisationer uppgår vid 2000talets början till 11 stycken.

Socialt arbete som begrepp förekommer sparsamt vid seklets början men användes i samband med Centralförbundet för Socialt Arbete (CSA). Vid den tiden talade man istället om t.ex. fattigvårds- och välgörenhetsarbete, verksamheter som kopplades ihop med filantropin. Den kopplingen rymmer såväl motsatta idéer om hur sociala problem skulle avhjälpas liksom olika uppfattningar om arbetet skulle bedrivas i frivillig eller statlig regi. CSA kom efterhand förespråka att det praktiska sociala arbetet skulle utföras av professionellt utbildade personer och att det skulle ske i statlig regi. Den vetenskapliga filantropins idéer om ett socialt reformarbete baserat på fakta och en vetenskaplig bas kom också att bli den tongivande inriktningen. 1909 startade förbundet den första kursen i socialt arbete. Från och med 1910 blev dessa kurser årslånga. 1920 beslutade CSA:s styrelse om att permanenta utbildningen och 1921 inrättades "Institutet för socialpolitisk och kommunal utbildning och forskning" (Lindholm 1993).

Utöver institutet i Stockholm inrättades socialinstitut i Göteborg 1944 och i Lund 1947. Efterhand inrättades utbildningar på ytterligare fyra platser i landet ett förhållande som rådde fram till 1990-talet. I dagens läge finns utbildningar i socialt arbete, ibland i kombination med social omsorg, vid en rad universitet och högskolor i landet. 
Stockholmsinstitutets namngivning var storslagen och signalerade etablerandet av ett institut för utbildning och forskning. Det visade sig emellertid att det fanns såväl ideologiska, akademiska och finansiella hinder på vägen. För att få det hela i hamn lyckades institutets blivande föreståndare docenten i nationalekonomi Gösta Bagge erhålla stöd från Rockefellerstiftelsen. I Bagges planer ingick också en professur i socialpolitik. Efter många turer kom en tjänst i nationalekonomi och socialpolitik att inrättas på donationsmedel, med Bagge som innehavare. Tjänsten var förlagd till Stockholm Högskola. Men eftersom dess innehavare samtidigt var föreståndare för Socialinstitutet så fanns en given personalunion och forskningsanknytning för institutet (Andreen \& Boalt 1987).

Frågan om forskning i relation till utbildningen av socialarbetare har alltså existerat lika länge som utbildningen. Utbildningens innehåll och organisering fick snabbt godtagbara lösningar medan frågan om forskning $i$ anslutning till utbildningen tog drygt 70 år att få en lösning på. Sammantaget utgör dessa olika delar grunden för dagens socionomutbildning, det praktiska sociala arbetet och dess utövande, olika kunskapssyner och relationen till forskning och vetenskap. Socialt arbete har starka band till identifiering och formulering av samtidens sociala problem liksom tilltron till den goda staten och dess förmåga att med vetenskaplig kunskap lösa dessa.

\section{Socialvetenskap som underlag och utvärdering av reformer}

"Den sociala frågan" debatterades i hela
Europa vid 1900-talets början. CSA kom att bidraga med en rad kartläggningar och producerandet av faktakunskaper. Man kan tala om en tradition av "sociala kartläggare« av vilka många stod CSA nära eller var bland dess ledande företrädare (för en diskussion om detta se Swärd "De sociala kartläggarna och hemlöshetsfrågan « i detta nummer).

Mellan de kartläggningar som ofta gjordes på privat initiativ och det statliga utredningsväsendet finns klara samband liksom mellan utredningsväsendet och den sociala forskningen. Det senare framgår av socialvetenskapliga forskningskommitténs betänkande angående "Socialvetenskapens ställning vid universitet och högskolor mm» (SOU 1946: 74). De sakkunniga konstaterar att den samhällsvetenskapliga "målforskningen" inom det offentliga utredningsväsendet är omfattande och att den expanderat de senaste decennierna samt att: "Omfattande undersökningar på detta område ha verkställts inom det offentliga utredningsväsendet. Många av de betänkanden som avgivits av olika kommittéer och särskilda sakkunniga, ha sålunda lämnat väsentliga bidrag till samhällsforskningen" (SOU 1946: 74, s. 16). Samtidigt konstaterar utredarna att den samtida socialvetenskapen intar en mycket blygsam plats i de akademiska lärosätenas organisation. Argumentationen i utredningen handlar om att beslutsfattarna behöver bättre beslutsunderlag i takt med att samhället blir alltmer komplicerat. De sakkunniga anser det också angeläget att man med vetenskapens hjälp skall kunna utvärdera resultaten av olika satsningar. Lika så betonas att de som arbetar med dessa frågor i 
såväl privat som offentlig tjänst måste få en bättre utbildning i sociala frågor. För att stärka socialvetenskapen föreslås fler tjänster vid universiteten och ett socialvetenskapligt forskningsråd.

Sociologi var ett av de ämnen som kom att inrättas som ett resultat av de ovan förda resonemangen. I de utredningar som föregick inrättandet av sociologi som akademiskt ämne vid svenska universitet framgår klart hur man från statens håll såg på ämnets funktion och innehåll. I den socialvetenskapliga forskningskommitténs betänkande från 1946 (SOU 1946:74) föreslås inrättandet av sociologi som eget akademiskt ämne i Sverige. Det sägs klart att man avser "den empiriska sociologin" med amerikansk inriktning och inte den "spekulativa" kontinentala. "Sociologins uppgift är att kartlägga det sociala fältets struktur och beskriva de olika krafter som äro verksamma inom detta fält. Vid en dylik kartläggning och beskrivning rör man sig framförall med en kvantitativ metod « (SOU 1946:74, s. 80).

Sociologen Gunnar Olofsson hävdar att det sätt som sociologin kom att utvecklas i Sverige innebar nya sätt att möta sociala problem och nya former för vetande och kunskap (Olofsson 1997) som en kedja av identifiering, kartläggning och klassificering av tidens sociala problem. Frågan om hur människor försörjer sig liksom arbetslöshet har länge varit ett etablerat socialt problem. Olofsson illustrerar sitt resonemang just med hur warbetslöshet" som begrepp och fenomen kommit att fungera som exempel på hur olika grupper med olika försörjningsproblem kom att urskiljas och delas in i olika grupper. Den klassificering som uppstod utgjorde sedan grunden för typ av stöd som det offentliga eller frivilliga krafter bistod med. Detta är innebörden i den nya typen av kunskap, "dvs kunskaper om vari de nya problemen om omständigheterna bestod, hur de uppkommit och vari de yttrat sig, hur de kunde mätas, om de ökade eller minskade etc." (Olofsson 1997, s. 240). Det växer fram ett systematiskt insamlande av empiri, begreppsliggörandet av en social problematik, orsaksanalyser och kopplingar till lösningar och åtgärder och utgör sammantaget ett "reformobjekt». Olofsson hävdar att detta är en del av den svenska samhällsvetenskapens historiska arv liksom sociologins utveckling till en "reformvetenskap". En del av den svenska sociologins historia är de stora kartläggningarna av befolkningens levnadsvillkor som nu finns institutionaliserade i Levnadsnivåundersökningarna (LNU) (för en utförlig redogörelse se Robert Eriksons artikel "Svensk välfärdsforskningu i detta nummer).

Olofssons analys, liksom de resonemang som förs under en period av välfärdsstatens expansionsskede avseende behovet av forskning, visar på en stark koppling mellan välfärdsstat, vetenskap och forskning. Det finns flera principiella likheter med de krav som i dagsläget ställs på forskningen i socialt arbete och det rimliga i att få kunskap om sociala insatsers effekter. Det handlar ytterst om statens legitimitet som rättrådig och god och om möjligheterna att fatta rationella beslut vad avser reformer och insatser.

När sociologin inrättades som universitetsämne var motivet främst att det inte längre var möjligt för politiker, myndighe- 
ter och beslutsfattare att ha kunskap och överblick över samhälleliga förhållanden och sociala problem. Samhället hade blivit så komplext att det krävdes en enhetlig och systematisk kunskap för att fatta de rätta besluten. Samma kunskapsbehov gäller fortfarande, men sedan 1950-talet när sociologin inrättades och 2000-talet har välfärdsstatens olika socialpolitiska system för försörjning, vård och omsorg byggts ut. Behovet av kunskap omfattar nu också systemens träffsäkerhet och effektivitet.

\section{Socialhögskolorna och forskningen}

1964 förvandlades socialinstituten till högskolor. Det föregicks av flera utredningar ( SOU 1964: 59) utan att frågan om forskningen fick en lösning som utbildningens företrädare och vissa intressenter ansåg vara tillfredsställande. Bl.a. framhölls behovet av forskning i socialpolitik och socialvårdsmetodik eftersom de kunskapsområdena inte behandlades inom andra befintliga ämnen. Man efterlyser också $i$ anslutning till socialvårdsmetodiken behovet av forskning i tillämpad psykologi. Förslaget för hur forskningen vid socialhögskolorna skulle lösas var att inrätta professurer vid socialhögskolorna med delad tjänstgöringsskyldighet i förhållande till universitet. Man betonar vikten av att endast genom att knyta tjänster till de blivande socialhögskolorna kan man få en inriktning som de blivande socialarbetarna var betjänta av. Rader av remissinstanser bl. a. Svenska Stadsförbundet, Svenska landskommuners förbund, SACO, TCO och Socialstyrelsen underströk behovet av ökade resurser för den sociala forskningen i dessa avseenden. I remissutlåtandet från Statskontoret uttalas emellertid en klart negativ hållning till att en knyta forskningsresurser till socialhögskolorna. Det ansågs orationellt att splittra tillgängliga resurser. Den ansvarige ministern delade Statskontorets uppfattning och frågan om den sociala forskningen lämnades till den socialpolitiska kommittén vars betänkande aviserades till nästkommande år.

Den socialpolitiska kommittén konstaterade sedan i sitt betänkande ett behov av att samla forskningen på det socialpolitiska området, och den föreslår ett forskningsinstitut, vars främsta syfte skall vara att »kartlägga socialpolitikens innebörd och verkningar" (SOU 1964:59, s. 49). I betänkandet framhålls särskilt vikten av att kommittén skall överväga vilka statistiska undersökningar som bör utföras i framtiden för att följa den socialpolitiska utvecklingen och tillföra kvalificerade beslutsunderlag. Kommittén begränsar sig till att se "socialpolitiken i mera inskränkt betydelse" (SOU 1964:59, s. 9). Med det avses allmänna och särskilda socialpolitiska åtgärder. De allmänna åtgärderna består av två huvudgrupper: ekonomiskt bistånd och personlig omvårdnad. Till det ekonomiska biståndet hör bl. a. socialhjälp och till personlig omvårdnad hör barn-, ungdoms- och nykterhetsvård liksom olika typer av hjälp och rådgivning.

I betänkandet förs också en diskussion om vad man skall förstå med "social forskning" och de olika syften den kan tjäna. Man nämner bl. a. dess funktion i utbildningen av de "som arbetar på det sociala området som planerare eller som socialar- 
betare i praktiskt fältarbete» (SOU 1964: 59 , s. 10) samt att forskningen också utgör en bas för socialt reformarbete. Betänkandet mynnar ut i ett förslag att inrätta ett forskningsinstitut och resultatet blev Socialforskningsinstitutet - SOFI - med koppling till Stockholms universitet.

När socialhögskolorna blev en del av det statliga högskoleväsendet var det ett sätt att höja dess status, däremot fanns ingen beredskap eller vilja att tillföra forskningsresurser. Forskning av direkt relevans för socialhögskolorna sorterades in som en del av den allmänna sociala forskningen. Frågan om forskning i direkt anslutning till utbildningsinstitutionerna var emellertid ständigt aktuell för de ansvariga för socionomutbildningen, och mot slutet av 1960talet gjordes nya försök att få professurer inrättande. Men med samma argument som tidigare avvisade regeringen propån, eftersom den uppfattades som ett försök att "splittra resurserna" (Berglind 1991).

Inför högskolereformen 1977 får frågan om socialhögskolorna och forskningen ny aktualitet. En grupp hade tillsatts för att utreda sociala linjens utbildning, forskning och inrättandet av ett forskningsämne, den s.k. SLU - gruppen (Arbetsgruppen för översyn av den Sociala Linjens Utbildning). Bland ledamöterna i gruppen fanns bl.a. Walter Korpi, nybliven professor $i$ socialpolitik vid SOFI och Hans Berglind med forskning om arbetslöshet som sitt specialområde. Båda Korpi och Berglind var sociologer och Berglind blev senare den förste professorn i socialt arbete vid Socialhögskolan i Stockholm. Berglind beskriver några av de idéer som var vägledande för gruppens arbete med att forma det nya profilämnet för sociala linjen. 1970-talet präglades av en radikal politisk debatt som även satte sin prägel på hur man ville att socialtjänsten skulle utvecklas i framtiden. I en diskussionspromemoria från 1975 lanserar arbetsgruppen "socialt arbete» som beteckningen på det nya forskningsämnet. Innehållsligt menar man att det skall ges samma innebörd som det som i internationella sammanhang kallas "social welfare». Det markeras också tydligt att socialt arbete inte skall uppfattas som liktydigt med social metodik utan att det: "har en väsentligt vidare innebörd än social metodik. Inom ämnets ram bör även rymmas undervisning och forskning som behandlar sociala åtgärder av mer generell och övergripande karaktär, såsom socialpolitik och social planering" (En diskussionspromemoria 1975, s. 10-11).

I SLU-gruppen fanns inledningsvis en restriktiv inställning till inrättandet av professurer. Man såg framför sig att forskningen skulle starta i begränsad omfattning och expandera efter hand. Men det slutliga förslaget kom istället att innebära en strategi att redan från början satsa på egna professurer. Motivet var främst att därigenom skapa en legitimitet i det vetenskapliga samhället. Förslaget innehåller också, starkt influerat av en amerikansk professor i social welfare Jerome Cohen, just betoningen på social welfare.

Berglind summerar de idéer som låg bakom den ämnesbeskrivning som gruppen levererade med följande ord: „Tanken var således att i forskning och undervisning studera de sociala problemens orsaker, konsekvenser och behandling" (Berglind 1991, s. 11). Formuleringarna är snubb- 
lande nära de som Olofsson återger för att karaktärisera sociologin som en reformvetenskap. Idémässigt finns alltså en koppling till ådran i svensk samhällsvetenskap och socialt arbete kan räknas in bland "reformvetenskapernaw. För den första professuren kom ämnet att formuleras på följande sätt:

Professuren $i$ socialt arbete är inriktad på studiet av sociala problem och àtgärder för lösning av dessa. Studieområdet innefattar analys av samhälleliga orsaker till sociala problem som drabbar individer och grupper av individer och deras sociala miljö. Området omfattar vidare analys av olika former för lösningar av sociala problem, utveckling av kunskaper som kan omsättas i förebyggande åtgärder för den praktiska verksamheten på det sociala området. I den verksamheten ingår samhällsplanering, social service för särskilda grupper, samhälls- och grannskapsarbete samt behandlingsarbete. Ämnesinnehållet baseras således på forskning som är tillämpad och tvärvetenskaplig.

Ämnet griper över olika nivåer och områden $i$ samhället: individ, familj, grupper, grannskap, arbetsliv och samhälleliga institutioner. Av särskild betydelse för ämnet är de sociala processer som förmedlar inflytande mellan olika samhällsnivåer.

Den sociala utbildningens behov och de socialt verksammas erfarenheter skall påverka inriktningen av forskningen $i$ socialt arbete. Forskningen skall medvetet organiseras så att dess resultat via grundutbildningen och via samarbete med fältet omsätts i praktisk tillämpningpå olika samhällsnivåer"(BäckWiklund 1993, s. 37-38).
Ämnesbeskrivningen är omfattande och speglar de tankegångar om en reformvetenskap med tillämpbar kunskap där de sociala fenomen som studeras binder ihop förklaringen med insatserna. Det framstår som en modern variant av svensk reformpolitik och kunskap för framtidens "sociala ingenjörer». Kunskapsproduktionen förutsätts ske på olika nivåer och mellan nivåerna. Det sociala praktikerfältet skall påverka inriktningen och forskarna skall leverera svaren i ett organiserat samarbete.

\section{Utbildning och yrkesroller}

Flera förhållanden kom initialt att påverka hur utbildningen vid det nyinrättade Socialinstitutet 1921 utformades. Det gäller framförallt synen på socialpolitik och hur de sociala problemen skulle lösas. Även inflytandet från USA och den på psykoanalytisk/dynamisk teori baserade case-work metoden brukar framhållas som viktiga inspirationskällor för hur den framväxande yrkesrollen i socialt arbete kom att formas (se t.ex. Lindholm 1988, Pettersson 2001, Swedner \& Swedner 1995).

Utbildningen byggdes till att börja med upp för att kunna förse de kommunala förvaltningarna med kunniga handläggare. Det sociala arbetet på fältet handlade vid den tiden om bostads- och hälsovårdsinspektion, personalarbete på arbetsplatser och kuratorsarbete, först och främst inom mentalvården. Kopplingen mellan socialt arbete och socialpolitik återspeglades i yrkesarbetet, det var dåtidens sociala frågor som stod i fokus för utbildningen. Denna beskrivning stämmer även för det $\mathrm{i}$ Göteborg 1944 inrättade Socialinstitutet 
(Ighe \& Fridén 1994). Det var de fattigas förhållanden mer än individer som isolerade personer eller familjer som avsågs. De sociala problemen identifierades på samhällsnivån men det uppfattades inte så att socialarbetarna skulle intervenera på dessa nivåer. De skulle via ett lagreglerat arbete bidraga till att problemen löstes på individnivå. "Kunskapen om sociallagstiftningen sågs i det perspektivet som en angelägnare grund än teoretiskt grundade metoder i klientbehandlingen" (Pettersson s. 126). Med tanke på den legalistiska inriktningen så var det vissa svårigheter att införa case-work i Sverige. Men metoden med sina olika varianter blev under lång tid det helt centrala i förberedelserna för yrkesrollen.

Det sätt som undervisningen inom de dåvarande socialinstituten organiserades ger en uppfattning om hur kunskapen sorterades och förmedlades. Det gjordes en strikt uppdelning mellan akademiska ämnen och de praktiska yrkesförberedande inslagen. Dessa olika verksamheter har också en tydlig könsprägel där manliga professorer och docenter svarade för att förmedla kunskap i de akademiska ämnena ekonomi, statskunskap och juridik. "Praktiska kursen « utgjorde förberedelserna för det praktiska arbetet och var delad i social förvaltning och social metodik. Den senare inriktningen var en exklusiv kvinnlig verksamhet (Lindholm 1988).

Tidigt kom psykologi, socialmedicin och socialhygien in i undervisningen. Den mentalhygieniska rörelsen inspirerade till en diskussion och bidrog med teoretiska influenser till det individinriktade sociala arbetet. Särskilt tydligt blev det när psykoanalytisk teori kom att införlivas med den annars så magra teoriarsenalen (Pettersson 2001, Kollind 2002). För socionomerna på den sociala linjen blev case-work importerat från USA den ledande metoden i mötet och arbetet med klienter. Många hämtade personligen in kunskap genom studieresor och förmedlade den ut i undervisningen. Men det fanns också ett nätverk av svenska kvinnliga intellektuella som, i ett tidigt skede i undervisningen av blivande socialarbetare, introducerade ett socialpsykologiskt och psykodynamiskt tänkande. Det är ett förhållande som ofta förbises i yrkesrollens svenska historieskrivning. USA med dess namnkunniga företrädare Jane Addams tillskrivs kanske en alltför stor betydelse av vad som faktiskt ägde rum tidigt i den svenska socialarbetarutbildningens historia. (För en analys av detta se Anna Karin Kollinds artikel «Kvinnor och socialt arbete - vid övergången från filantropi till profession« i detta nummer).

För att få en vetenskaplig förankring sökte de verksamma inom området att etablera en koppling till psykiatrin. I USA var de psykiatriskt/analytiskt skolade socialarbetarna de som stod högst i klass. I den amerikanska utvecklingen fanns en dubbelhet som man även kan känna igen i Sverige. Det var strävan att bygga det sociala arbetet på vetenskaplig grund samtidigt som det fanns en uttalad skepsis mot universiteten och det då rådande positivistiska vetenskapsidealet. Det fanns och finns en uppfattning att socialt arbete är så speciellt att endast erfarna praktiker kan genomföra forskning på området (Pettersson 2001).

Det byråkratiska inslaget i den svenska socialarbetarrollen framhävs ofta (Pettersson 2001). Men utvecklingen i Sverige gick 
egentligen mot två radikalt olika yrkesroller. Den ena var byråkraten och handläggaren som stöder sig på lagen och den andra behandlaren med stöd i psykodynamisk teoribildning. Eftersom socialarbetare arbetar med stöd av lagen finns alltid ett inslag av kontroll. Makten - dold eller uttalad - ses ofta som ett problem särskilt som professionalitet förknippas med personligt stöd och behandling genom en bärande relation. Det är i den betydelsen som professionellt socialt arbete oftast används (Lindholm 1988, Pettersson 2001), en innebörd som inte helt stämmer överens med den i professionsforskningen vedertagna, där yrkesgruppens kollektiva strävanden och avgränsning gentemot andra yrkesgrupper och hävdande av eget kunskapsmonopol utgör det viktigaste kriteriet (Hellberg 1978).

Förslaget till det nya forskningsämnet arbetades fram under en period av påtaglig radikalisering av det svenska samhället. Från 1950-talet och framåt hade de sociala förvaltningarna i landets kommuner expanderat och 1960-talet innebar ytterligare expansion. Det förde med sig att många tidigare "sanningar" ifrågasattes, så även case-work. Samhällsarbete och strukturinriktat arbete fördes fram som nya alternativa metoder för socialarbetare. De traditionella hörnstenarna, socialpolitiskt och individinriktat arbete, aktualiserades fast nu $\mathrm{i}$ en annan terminologi, nämligen samhällsarbete och psykosocialt arbete. Samhällsarbete blev ett inslag i utbildningen som ett komplement eller ibland i motsatsställning till den traditionella individinriktningen i klientarbetet. På fältet etablerades rader av projekt för att möta de växande problemen i miljonprogrammens bostadsområden (se t.ex. Gunnel Swedner 1969, Harald Swedner m.fl. 1970).

I och med reformeringen av den sociala linjen, den s.k. SLU-reformen och inrättandet av det nya ämnet socialt arbete så inleddes också ett arbete med att skaffa det nya ämnet en egen identitet. Det nya ämnets karaktäristika och dess relation till arbetsfältet och klienterna utgjorde en dominerande andel av retoriken (Bäck-Wiklund 1993).

När socialt arbete inrättats som eget ämne var case-work i dess olika varianter ett passerat skede liksom ett renodlat individinriktat arbetssätt. Men i dess spår spirade en ny retorik kring psykosocialt arbete, där individen fortfarande står i centrum men inplacerad i sin sociala omgivning. Det psykiska blev socialt eller "psykosocialt» och det sociala blev psykiskt, eller "socialpsykologiskt». 1970-talet innebar att den svenska socialpsykologin vitaliserades genom att sociologen och samtidsfilosofen Johan Asplund skapade nytt liv i den symboliska interaktionismen (Asplund 1968). Dessa nygamla tankar hade ett stort inflytande i 1970-talets tänkande kring individ och samhälle. I såväl det psykosociala som inom socialpsykologin återfinns antagandet om att det är ett grundläggande mänskligt behov att relatera sig till andra människor.

I syfte att ge klientarbetet en teoretisk bas producerades en mängd böcker med fokus på samspelet mellan socialarbetaren och klienten. (Hessle 1985, Bernler \& Johnsson 1991 Lennér-Axelsson, \& Thylefors 1999).

\section{Yrkesroll utan yrkesmonopol}

1958 slöt sig socionomerna samman i Aka- 
demikerförbundet SSR. 1950-talet hade inneburit en expansion för yrkesgruppen. 1960-talet innebar ytterligare expansion samtidigt som det kom till en mängd nya funktioner i det praktiska sociala arbetet. Frågan om statlig legitimation för socialarbetare aktualiserades tidigt inom förbundet. Men det var egentligen först i samband med den statliga s.k. behörighetskommittén 1980 som frågan tog fart på allvar och då för kuratorer inom hälso- och sjukvården. Kommitténs uppgift var att se över frågor avseende behörighet och legitimering inom hälso- och sjukvården. För att följa och bevaka hur ärendet utvecklades tillsatte SSR en egen kommitté, och vid förbundets kongress 1981 fattades beslut om att kräva legitimation knuten till socionomexamen. Kravet var generellt men argumenteringen utformades i anslutning till kuratorer och psykoterapeutiskt verksamma socionomer. Behörighetskommittén avvisade i sitt betänkande SSR:s krav med motiveringen att legitimation endast är aktuell för yrken med kvalificerade arbetsuppgifter och med stort ansvar för enskilda, samt att de verksamma skulle ha en självständig funktion (Wingfors 2001).

1988 aktualiserade SSR:s styrelse frågan om socialarbetarna och deras behörighet och yrkeskompetens återigen, men denna gång som en "självadministrerad legitimation", som skulle benämnas auktoriserad socionom. Arbetet stannade upp bl. a. genom den intensiva debatt om det sociala arbetets villkor som förorsakades av några uppmärksammade fall av barnmisshandel varav ett med dödlig utgång. I det sammanhanget tog SSR återigen upp frågan om statlig legitimation bl. a. med stöd av motioner från företrädare för flera politiska partier. Socialutskottet avvisade dock de nya propåerna, men aviserade samtidigt en ny översyn. Socialstyrelsen uttalade med hänvisning till sina tidigare ställningstaganden stöd för en restriktiv hållning. Även den nya översynen som presenterades 1996 (SOU 1996:138) innebar ett negativt besked avseende statlig legitimation för socionomerna. Frågan hänsköts också till arbetet med revideringen av socialtjänstlagen. Men inte heller i detta sammanhang nåddes några framgångar i kampen för en statlig legitimation för socialarbetare. Inom SSR hade dock arbetet med auktorisation i egen regi fortgått, och 1997 fastställdes ramarna för densamma. Samma år tog förbundet det formella beslutet och i februari 1998 fastställs reglerna för auktorisation och Nämnden för Socionomauktorisation inrättades.

Sociolog Stina Wingfors konstaterar i sin genomgång av SSR:s argumentation och kamp för att ge socionomer statlig legitimation, att de skäl som framhållits varit av mycket generell karaktär. Detta i motsats till t. ex. Socialstyrelsens klart uttalade krav att det är det specifika i yrkesrollens uppgifter som skall vara grunden. I de fall de fackliga kraven varit specifika så har detta gått att återföra till en behandlarroll - egentligen det som man av tradition velat se som kärnan i det sociala arbetet. Man kan tillägga att utbildningen av socialarbetare brukar ses som en "generalistutbildning». Bl. a. en följd av arbetsfältet och arbetsuppgifternas stora spridning och att specialisering sker senare i yrkeskarriären. Möjligheterna till vidareutbildning är förhållandevis bra, bl. a. finns en magisterut- 
bildning och utbildning för handledare till praktiskt verksamma socialarbetare. Många socialarbetare har också kvalificerade specialkunskaper inom sitt område. På samma sätt som variationen i arbetsuppgifter, så gäller variation vad avser kvalifikationerna. De krav som uppställs för att erhålla den självadministrerade auktorisationen är till stora delar förhållandevis generella bortsett från det specifika kravet på godkänd handledning av godkänd handledare. Kanske hade man kunnat nå längre om man specificerat kraven för olika avgränsade arbetsuppgifter. Kanske är ovilja att differentiera en facklig strategi och ett sätt att inte splittra socialarbetarna som yrkesgrupp?

\section{Socialt arbete - ett begrepp med många dimensioner}

Vad betyder då de historiska rötterna för synen på kunskap i relation till socialt arbete? Att skapa en vetenskaplig legitimitet för det sociala arbetet kom tidigt på den utbildningspolitiska dagordningen. Det långa perspektivet visar emellertid att det tog närmare 70 år att etablera forskning i direkt anslutning till utbildningen av socialarbetare. Under tiden blev sociologi ett ämne vid svenska universitet. Socialforskningsinstitutet (SOFI) skapades bl. a. för att följa utfallen av den svenska socialpolitiken, till vilken också en stor del av socialtjänstens verksamhet räknas. Från 1950-talet och framåt växte sig psykologin stark inom de svenska universiteten. Givet denna utveckling fanns förutsättningarna för att viktig kunskap för socialtjänstens verksamheter skulle skapas. Men ansvariga för utbildningen av socialarbetare, socialar- betarna själva liksom deras fackliga företrädare uppfattade inte, att kunskapsproduktionen inom de ovan nämnda forskningsområdena motsvarade de egna behoven. En stor del av de frågor som upplevdes som relevanta för de yrkesarbetande blev aldrig föremål för forskning, inte heller skapades kunskap om de långsiktiga effekterna av flertalet av socialtjänstens insatser. Så när de egna professurerna inrättades i socialt arbete i direkt anslutning till utbildningen, var förväntningarna stora på vad forskningen inom det "egna forskningsområdet" skulle kunna åstadkomma. I ett sådant läge tenderar vetenskapens betydelse att överskattas och synfältet att begränsas till endast socialt arbete. Från sekelskiftet och framåt har många forskningsområden av relevans för socialt arbete skapats inom den svenska universitets- och högskolevärlden.

Delar av retoriken kring forskningsämnet socialt arbete har stora likheter med den som användes när sociologin etablerades. Själva idén med reformvetenskapen är att studera de sociala problemens orsaker och utbredning och koppla lösningarna till grupper och kategorier av människor. Men i det praktiska sociala arbetet är det individinriktade arbetet och mötet med klienten det som ofta betraktas som själva kärnan i det professionella arbetet. Socialarbetarna har också under lång tid sökt erhålla statlig legitimation för att få sin professionalitet erkänd - utan att lyckas.

Bengt-Åke Armelius, psykoterapeut och professor i klinisk psykologi, reflekterar över synen på det sociala arbetets "vetenskaplighet" i relation till den debatt som varit och fortfarande är aktuell avseende den kliniska psykologin. Han hävdar att 
diskussionen om den kunskapsbaserade socialtjänsten har många drag gemensamt med den avseende den kliniska psykologin. Många av de låsningar som fanns i såväl debatten som i forskningen är på väg att lösas upp och det finns anledning att tro på en liknande utveckling inom socialt arbete (Armelius 2002).

Psykologer och socialarbetare finns i många sammanhang inom samma arbetsfält och i olika sammanhang har tvister om gränsdragningen mellan yrkesgrupperna förekommit. Psykologerna fick sin statliga yrkeslegitimation på 1970-talet, trots att den etablerade forskningen i liten utsträckning bidrog till dess vetenskapliga bas (Rigné 2002). Socialarbetarna har drivit frågan om statlig legitimering länge utan att lyckas. Flera grupper bland socialarbetarna besitter i dagens läge kunskaper som väl låter sig jämföras med många psykologer. Det sociala arbetsfältet är stort och varierat liksom yrkesgruppens kompetens och den forskning som står till buds, och att se socialt arbete som ett kunskapsområde ter sig alltmer tveksamt.

Själva begreppet socialt arbete hör ursprungligen ihop med Centralförbundet för Socialt Arbete och organisationens kraftsamling för att skapa debatt, upplysning och kartläggning av "den sociala frågan". De verksamheter som initierades med omfattande kartläggningar av fattigdom, hemlöshet och ohälsa utgör nu en del av den svenska välfärdsforskningens arv. Men fortfarande är identifieringen och formuleringen av samtidens sociala problem centralt i såväl forskning som praktisk verksamhet inom socialt arbete. Från forskningens perspektiv innebär detta också att den reflekterande och kritiska blicken riktas mot såväl beslutsfattare som verksamheter inom det sociala fältet. Kritik är inte alltid välkommen, men ett viktigt inslag i en välfärdsstat med så omfattande åtaganden som den svenska. Det visar inte minst debatten om det kunskapsbaserade sociala arbetet. Den har till stor del fokuserat forskningens innehåll/ objekt och metoder. Men frågan är betydligt större och om forskningens resultat kan användas beror också på användaren. Tommy Lundström professor i socialt arbete och medförfattare till Välfärdsbokslutet, konstaterade ställd inför uppgiften att analysera kommunernas sociala barnavård, att det saknades systematiserade och säkra kunskaper liksom vilka effekter arbetet har (Lundström 2000).

Ett annat förhållande är relationen mellan yrkesverksamma och forskningsaktiva inom socialtjänsten betraktat utifrån antalet människor det handlar om. Om man ser kunskapsuppbyggnaden ensidigt från forskning till fält så är den numerära relationen mellan yrkesverksamma och forskningsaktiva minimal. Om man istället ser kunskapsuppbyggnaden som ett samspel mellan forskning och fält är förutsättningarna inte mycket bättre. Forskarutbildade verksamma på det sociala praktikerfältet är få, liksom de karriärvägar som står till buds.

Mycket talar för att det fanns mycket olika förväntningar på socialt arbete som forskningsämne. Drygt 20 år är en kort tid för att etablera ett forskningsämne med en så varierad praktik där företrädarna måste balansera mellan legitimitet inom såväl det vetenskapliga samhället som på 
praktikerfältet. Kunskapstillväxten är också ojämn, men forskningsmässigt har socialt arbete kommit att utvecklas på bred front med en begynnande specialisering till vissa områden. Sune Sunesson en av de fyra första professorerna i socialt arbete lyfter fram barn, familj, missbruk och försörjning (Sunesson 2000). Peter Dellgran och Staffan Höjer (2002), forskare i socialt arbete, visar i en empirisk studie av den seniora forskningens innehåll en något annorlunda profil vad avser kunskapsområden och mängden forskning. De finner att omsorg, missbruk och barnavård i dagsläget är välförsörjda vad avser forskning. De visar också att forskningens innehåll till en tred- jedel utgörs av studier av sociala företeelser och fenomen av olika slag. Resten - två tredjedelar - utgörs av interventionsforskning på såväl mikro som makronivå. Av interventionsforskningen kan något under 20 procent sägas ha utvärderande ambitioner dvs. att "studera implementering, konsekvenser, utfall el. dyl. av de verksamheter som står i fokus« (Dellgran och Höjer 2002, s. 12).

Den kritik som riktas mot socialt arbete för att inte utvärdera effekter av olika sociala insatser stämmer till betydande del, men det kan inte jämställas med att forskningen inte bidrar till att skapa en säkrare kunskapsbas för socialt arbete.

\section{Referenser}

Andreen, Per.G. \& Boalt, Gunnar (1987) Bagge fär tacka Rockefeller. Rapport i socialt arbete, $\mathrm{Nr}$ 30-1987. Stockholms Universitet - Socialhögskolan.

Armelius, Bengt-Åke (2002) Diskussionen om en evidensbaserad socialtjänst - en dejà-vu upplevelse. I Socialvetenskaplig Tidskrift vol 9 nr: 2-3 s. 261-265.

Asplund, Johan (1968) Sociologiska teorier. Lund: Studentlitteratur.

Berg, Lars-Erik (1995) „Den sociala människan: Om den symboliska interaktionismen«. I Månsson, Per (red) Moderna samhällsteorier. Traditioner, riktningar, teoretiker. Stockholm: Rabén Prisma.

Berglind, Hans (1991) »10 års forskning i socialt arbete» . I Berglind, Hans \& Kristensson, PerOlov (red.) Socialt arbete $i$ utveckling. Stockholm: Allmänna förlaget.

Bernler, Gunnar \& Johnsson, Lisbeth (1991) Teori för psykosocialt arbete. Stockholm: Natur och Kultur.
Bäck-Wiklund, Margareta (1993) Vetenskap och politik $i$ socialt arbete. Göteborgs Universitet. Institutionen för socialt arbete Rapport 1993:8.

Dahlström, Edmund (1980) Samhällsvetenskap och praktik. Studier $i$ samhällelig kunskapsutveckling. Stockholm: Publica.

Dellgran, Peter \& Höjer, Staffan (2000) Kunskapsbildning och professionalisering $i$ socialt arbete. Akademisk avhandling, Göteborgs Universitet. Institutionen för socialt arbete.

Dellgran, Peter \& Höjer, Staffan (2002) Forskning i praktiken. Om den seniora forskningens innehaill och socionomernas forskningsorientering. Göteborgs Universitet, Institutionen för socialt arbete. Rapportmanus version ldec 2002 i den kommande nationella utvärderingen av socialt arbete.

Egelund, Tine (1999) Analyse af handlederutdannelserne i Göteborg, påSköndal og i Umeå. CUS skrift 1999:6. Socialstyrelsen.

Gerdman, Axianne m fl (2000) Grov misstolkning av handledarutbildningarna i Socionmen 2000/1. 
Granqvist, Nina (1997) Privatisering i princip och praktik. Åbo: Åbos Akademis Förlag.

Hellberg, Inga (1978) Studier i professionell organisation. Akademisk avhandling. Göteborgs Universitet, Sociologiska Institutionen.

Hessle, Sven (1985) Riktlinjer för psykosocialt arbete. Stockholm: AWE/Geber,

Ighe, Ann \& Fridén, Bertid (1994) När meninghetsbesvär skulle bli tjänstetid. Ett femtioårsperspektiv på socionomutbildningen $i$ Göteborg. Göteborgs universitet, Institutionen för socialt arbete.

Kihlström, Anita \& Karlsson, Per-Åke (1996) Doktorander i socialt arbete. Forskningsrapport. Göteborgs Universitet, Institutionen för socialt arbete.

Kollind, Anna-Karin (2002) Äktenskap, konflikter och rådgivning. Från medling till samtalsterapi. Stockholm: Carlssons.

Leennér-Axelsson, Barbro \& Thylefors, Ingela (1999) Psykosocialt behandlingsarbete. Stockholm: Natur och Kultur.

Lindholm, Kerstin (1988) Den sociala utbildningens identitet. Rapport från ett projekt om socialt arbete. Rapport $i$ socialt arbete $43-1988$. Stockholms Universitet -Socialhögskolan.

Lindholm, Kerstin (1993) En kort historik 19031993 inför 90-års-jubiléet. Stockholm: Centralförbundet för socialt arbete.

Lundström, Tommy (2000) Om kommunernas sociala barnavård i SOU 2000:38, Välfärd, vård och omsorg. Stockholm: Kommittén/ Välfärdsbokslutet.

Månsson, Sven-Axel (2000) „Kunskapen inom Socialtjänsten och den akademiska forskningen - drar vi åt samma hållı? Socionomen 8/2000.

Månsson, Sven-Axel (2002) "Att förstå sociala insatsers värde». I Kunskap, erfarenhet och intuition, FOU: Skåne. Skriftserie 2002:2.

Möller, Tommy (2002) Välfärdsstaten utmaningar och demokratins villkor i Solidaritet med undantag. Försäkringskasseförbundet Fakta \& Debatt, Nr 2:2002.

Olofsson, Gunnar (1997) Socialvetenskapen och de sociala problemen. I Socialvetenskaplig Tidskrift vol. $4 \mathrm{nr} 3$, s. 236- 251.
Pettersson, Ulla (2001) Socialt arbete, politik och professionalisering. Den historiska utvecklingen $i$ USA och Sverige. Stockholm: Natur och Kultur.

Qvarsell, Roger (1995) "Mellan familj, arbetsgivare och stat. En idéhistorisk essä om det sociala ansvarets organisering under två århundraden". I Erik Amnå (red) Medmänsklighet att hyra? Örebro: Bokförlaget Libris.

Rigné, Eva-Marie (2002) Profession, Science and the State. Psychology in Sweden 1968-1990. Akademisk avhandling. Göteborgs Universitet, Sociologiska Institutionen.

Rothstein, Bo \& Kumlin, S. (2001) Demokrati, socialt kapital och förtroende i Holmberg, Sören \& Weibull, Lennart.(red) Land du välsignade. SOM-rapport 26, Göteborgs Universitet, SOM-institutet, 2001.

SOS-rapport 2000:1. Nationellt stöd för kunskapsutveckling inom socialtjänsten.

SOU 1946:74 Betänkande angående socialvetenskapernas ställning vid universitet och högskolor m.m.

SOU 1964:59 Ett socialpolitiskt utredningsinstitut. Förslag av socialpolitiska kommittén.

SOU: 2000:3, Välfärd vid vägskäl Delbetänkande under 1990-talet. Stockholm: Delbetänkande/ Kommittén Välfärdsbokslutet.

Sunesson, Sune (2002) "Socialt arbete som internationellt forskningssområde». I Meeuwisse, Anna m.fl (red) Socialt arbete. En grundbok. Stockholm: Natur och Kultur.

Swedner, Harald m.fl. (1970) Rapport från Öst ergård. Sociologiska Institutionen, Lunds Universitet

Swedner, Gunnel (1969) Socialarbetaren och Samhällsförändringen. Samhällsarbete som en metod $i$ socialt arbete. Lund: Studentlitteratur.

Swedner, Gunnel \& Swedner, Harald (1995) Pionjärer $i$ socialt arbete. Om Jane Addams och hemgården Hull House. Stockholm: Liber utbildning.

Tengvald, Karin (1995) Behov av resultatorienterad kunskapsutveckling i socialt arbete. Bilaga 6 i SOU 1995:58 Kompetens och kunskapsut-

Margareta Bäck-Wiklund: Kunskapens värde och samhällets behov. 
veckling - om yrkesroller och arbetsfält inom socialtjänsten. Stockholm, Socialdepartementet.

Tengvald, Karin (2001) »Kunskapsutvecklingen av socialt arbete - för klientens bästa». Socionomen 1/2001.

Wigzell, Kerstin (1999) „Personalen skyddas - inte klienterna». I Dagens Nyheter den 26 januari 1999.

Wingfors, Stina (2001) "Legitimation och egenauktoroisation som inslag i en professionell strategi. Exemplet socionomer". I TAM-Revy 2:2001

\section{Källor}

Campbell Collaboration. Programskrift.

En diskussionspromemoria maj, 1975. SLU-gruppens översyn av sociala linjens utbildning. Nämnden för socionomutbildning.
Socialvetenskapliga forskningsrådets årsredovisning 1999.

Stadgar för Centralförbundet för socialt arbete. Fastställda av Kunglig. Maj:t 1921 reviderade 1959 och 1974.

\section{Summary}

\section{The value of knowledge and the needs of society}

Social work as a concept was originally used around 1900 in relation to The Central Association for Social Work (CSA). Vocational education for social workers was established soon after through an initiative from CSA, but it took more than 70 years to establish research and professorships in social work. The first professorship came in 1979. During the twentieth century various dimension, sometimes contradictory, were included in the concept. Social work is one in a range of applied social sciences established in relation to the expansion of the welfare state in order to produce valuable knowledge for decision making, social reforms and practical social work. The status as an applied social science creates pronounced expectations about what could be achieved through researchbased knowledge, as expressed by social workers, politicians and from the scholarly community itself. It also makes social work research the target for criticism from these actors. Through the historical perspective it becomes evident that the knowledge base for applied social work far exceeds what is produced in the new discipline. Sociology, psychology and social policy are also disciplines covering topics of interest to social work. Comparisons with other applied sciences such as medicine show that social work research and its relation to the practice field is weak and undeveloped. However social work is a discipline in progress, and an overview of social work research shows that some topics such as care, family and children, drugs and poverty are areas with an extensive growth of knowledge, with potential both as an applied science and as "pure» social science. 